\title{
EMPOWERMENT STRATEGIES OF MICRO, SMALL, MEDIUM ENTERPRISES (MSMES) TO IMPROVE INDONESIA EXPORT PERFORMANCE
}

\author{
Muhammad Adi Adrian \\ Institut Agama Islam Negeri Salatiga \\ adiadrian779@gmail.com
}

\begin{abstract}
In international trade itself can not be separated from the export and import sectors. One way that can be done to increase the value of exports is to improve the empowerment of products Micro, Small, Medium Enterprises. MSMEs is considered to be a solution in improving the economy in Indonesia. But the development of the era makes the challenges facing MSMEs is getting higher. The strategy that can be done by umkm in overcoming the development of the times is by the control of the market. However, in order to dominate the market, MSMEs need to get information easily and quickly to expand the marketing network of MSMEs. other than that Information technology application on MSMEs will facilitate in expanding the market both in the country and overseas markets and the establishment of IT-based MSMEs Development Center.
\end{abstract}

\section{Key Word : Export Performance, MSME, Empowerment}

\section{INTRODUCTION}

In the context of a country's economy, one of the prominent problems is about economic growth. Although there are also other problems regarding unemployment, inflation or rising prices of goods simultaneously, poverty, income distribution and so forth. Economic growth is important in the economic context of a country because it can be one measure of the growth or achievement of the nation's economy, although other measures cannot be denied. Wijono in Jimmy (2005) states that economic growth is one indicator of development progress.

One of the drivers of the economy through international trade. With international trade, it is expected to increase economic growth in a country. Salvatore in Jimmy (2004) states that trade can be a machine for growth. International trade cannot be separated from the existence of Export and Import activities. In its development, the amount of exports in Indonesia is much lower compared to the amount of imports. BPS noted that the value of Indonesian exports in April 2018 reached US \$ 14.47 billion or decreased by 7.19 percent compared to exports in March 2018. Meanwhile, Indonesia's import value for April 2018 reached US \$ 16.09 billion, up 11.28 percent compared to March 2018.

The high value of imports in Indonesia can threaten the selling value of domestic products and make people dependent on imported products themselves. Therefore, Indonesia needs to increase the export value in order to increase the value of exports so that domestic products are not inferior to 
imported products. One way that can be done to increase the value of exports is by increasing the empowerment of MSME products (Micro, Small, Medium Enterprises). MSMEs are considered to be a solution in improving the economy in Indonesia. It was evident that in the 19922000 crisis the MSMEs were regarded as the saviors of the Indonesian economy because they were able to survive in the crisis and become the pillars of the Indonesian economy at that time (Manurung, in Sri Wahyuningsih. 2007). In addition, MSMEs are also able to absorb a lot of labor which can reduce the unemployment rate in Indonesia.

The Ministry of Cooperatives and SMEs noted that in 2016 the MSME sector contributed Indonesia's Gross Domestic Product (GDP) of 4.41 percent, an increase from the previous year which was only 1.67 percent. Increasing the MSME sector in increasing Indonesia's GDP makes MSMEs a driver of the Indonesian economy and can open opportunities that the Indonesian economy will develop in the future. MSMEs are also considered capable of being a solution for Indonesia to improve the Indonesian economy internationally.

The development of MSMEs in Indonesia is still faced with a variety of problems, causing weak competitiveness of imported products. The main problems faced by MSMEs include limited infrastructure and government access related to licensing and bureaucracy and high rates of levies. With all the problems that exist, the potential of large MSMEs becomes hampered. Although MSMEs are said to be able to withstand the global crisis but in reality the problems faced are very many and heavier. That is because in addition to being indirectly affected by the global crisis, MSMEs must also face domestic problems that have not been resolved such as the problem of labor wages, employment and illegal fees, corruption and so on.

Another problem faced by MSMEs is the liberalization of trade or the free market. This condition will be more difficult for Indonesian MSMEs to face at this time, because the condition of MSMEs in Indonesia is still not stable, there are still many problems faced by MSMEs but the challenges have been added to the existence of the free market. If this condition is allowed, MSMEs that are called capable of surviving and resilient will eventually go bankrupt too. Therefore, in an effort to strengthen MSMEs as a national economic fundamentals, it is necessary to create a conducive domestic investment climate in an effort to strengthen the domestic market so that MSMEs can become a buffer for the national economy.

Another problem faced and at the same time become the weakness of MSMEs is the lack of access to information, especially market information (Isaac, in Sudaryanto, et.al 2005). This is an obstacle in terms of marketing its products, because of the limited access to market information which results in low market orientation and weak competitiveness at the global level. The low level of information about these markets, makes MSMEs unable to direct the development of their businesses clearly and focus, so that their development stagnates. The ability of MSMEs to deal with the global flow of competition is indeed necessary to think further in order to remain able to survive for the stability of the Indonesian economy. In addition, the human resources factor in it also has its own contribution. The strategy for developing 
MSMEs to survive can be done by increasing competitiveness and human resource development in order to have value and be able to improve Indonesia's export performance, including through credit distribution (KUR), providing access to marketing information, training microfinance institutions through capacity building, and development information technology (IT).

Likewise, other efforts can be made through campaigns to love domestic products and provide injections of funding to microfinance institutions. Microfinance has become a global discourse that is believed by many to be a method to overcome poverty. Various multilateral and bilateral institutions develop microfinance in various cooperation programs. Governments in several developing countries have also tried to develop microfinance in various development programs. Nongovernmental organizations are also not left behind to take part in the application of microfinance (Prabowo and Wardoyo in Sudaryanto, et. Al, 2003).

Based on this explanation, the study of MSME Empowerment Strategy to improve the performance of Indonesian exports is important to do. Considering both activities are economic activities that have the potential to provide a large contribution to the improvement of the Indonesian economy internationally. The results of this study are expected to be used as one of the reference materials in determining the role of MSMEs in improving the economy in Indonesia. It is hoped that this writing study can support and enhance each other so that they can make a more maximal contribution in improving the national economy.

\section{RESEARCH METHODS}

In this writing using a descriptive method, doing the analysis only reaches the descriptive level, which is analyzing and presenting facts systematically so that they can be easier to understand and conclude. Descriptive research is research that seeks to describe problem solving that is now based on data, so this descriptive also presents data, analyzing and interpreting (Narbuko in Adnan, 2007). The conclusion given is always clear on the factual basis so that everything can always be returned directly to the data obtained. Description of conclusions is based on numbers obtained not too deep. Discussion of the problem by using literature studies and secondary data as a source of information, then the data is analyzed to be interpreted. From existing data sources and literature studies, problem solving solutions can be sought.

\section{RESULT AND DISCUSSION Understanding of MSMEs}

In the Indonesian economy, MSMEs are the largest group of companies and are proven to be resistant to various types of economic crisis shocks. Criteria for businesses included in Micro, Small and Medium Enterprises are regulated in the legal umbrella. Based on Law Number 20 of 2008 concerning Micro, Small and Medium Enterprises (MSMEs) there are several criteria that are used to define the definition and criteria of Micro, Small and Medium Enterprises.

In Law Number 20 of 2008, Micro Enterprises are productive businesses owned by individuals and or business entities that meet the criteria of Micro Businesses as stipulated in this Law. Small-scale business is a stand-alone 
productive economic undertaking carried out by individuals or business entities that are not subsidiaries or not branches of companies that are owned, controlled, or become part of either directly or indirectly from medium-sized businesses or large businesses that meet the criteria of Small Businesses as referred to in this Act. Medium Enterprises are productive economic activities that are independent, carried out by individuals or business entities that are not subsidiaries or branches of companies that are owned, controlled, or become part of either directly or indirectly with Small Businesses or large businesses with a total net worth or annual sales proceeds as stipulated in this Act.

According to the Ministry of State for Cooperatives and Small and Medium Enterprises in Sudaryanto, et.al (2012) what is meant by Small Businesses (UK), including Micro Enterprises (UMI), are business entities that have a net worth of at most Rp. 200,000,000, not including land and building of business premises, and has annual sales of at most Rp.1,000,000,000. Meanwhile, Medium Enterprises (UM) are business entities owned by Indonesian citizens who have a net worth greater than Rp. 200,000,000. IDR 10,000,000,000, excluding land and buildings.

While the Central Statistics Agency (BPS) provides a definition of SMEs based on the quantity of labor. Small business is a business entity that has a total workforce of 5 to 19 people, while a medium business is a business entity that has a workforce of 20 s.d. 99 people. Based on the Decree of the Minister of Finance No. 316 / KMK.016 / 1994 dated June 27, 1994, small businesses are defined as individuals or business entities that have carried out activities / businesses that have sales / turnover per year as high as Rp.600,000,000 or assets / assets as high as Rp.600,000,000 (outside the land and the occupied building) consisting of badang business (Fa, CV, PT, and cooperatives) and individuals (craftsmen / home industries, farmers, ranchers, fishermen, forest encroachers, miners , merchants of goods and services).

\section{Understanding of Export}

According to Todaro in Jimmy (2002: 49) International trade activities that provide useful stimuli require domestic demand which causes the growth of large factory industries, together with a stable political structure and flexible social institutions. Based on the description above, it can be seen that exports reflect trade activities among nations that can provide a boost in the dynamics of growth in international trade, so that developing countries are likely to achieve economic progress in line with more developed countries.

Exports are purchases of other countries for goods made by domestic companies. The most important factor that determines exports is the ability of the country to issue goods that can compete in foreign markets. Exports will directly affect national income. However, the reverse relationship does not always apply, namely an increase in national income does not necessarily increase exports because national income can increase as a result of increases in household expenditure, company investment, government expenditure and replacement of imported goods with domestically-made goods. (Sukirno in Jimmy, 2008: 205-206). 


\section{ISSN: 2614-1280}

http://www.jurnal.stie-aas/ijebar

\section{Position of MSMEs in Exports}

Currently, the export structure of Indonesia's MSME products comes mostly from processing industries such as furniture, food and beverages, apparel or garments, wood and rattan industries, agricultural products, especially plantations and fisheries, while in the mining sector it is still very small (only those related to rock, clay and sand). In detail the export goods of MSMEs include household items, ready-made clothing or garments, batik, other finished goods from leather, wooden handicrafts, gold or silver jewelry, children's toys, wicker, goods from rattan, fish processing, furniture, shoes or leather footwear, wood charcoal / shells, snacks and embroidery products. While the raw materials for MSME production used are the remaining local raw materials from imports such as plastic, leather and some chemicals. In the table below, Indonesia's total non-oil and gas exports in 2013 reached $182,112.7$ billion. This proves that the contribution of MSMEs to exports is quite high but still below the amount of non-oil exports produced by large businesses. This is what is becoming a challenge for the umkm to be able to compete in the future.

Table 1. Data on the Number of Non Oil and Gas Exports 2013 MSMEs and Large Enterprises

\begin{tabular}{|c|l|r|r|r|}
\hline \multirow{2}{*}{ NO } & \multicolumn{1}{|c|}{ INDICATOR } & \multicolumn{2}{|c|}{ UNIT } & \multicolumn{2}{|c|}{ YEAR 2013} \\
\cline { 4 - 5 } & & & \multicolumn{1}{c|}{ TOTAL } & \multicolumn{1}{c|}{$\begin{array}{c}\text { MARKET SHARE } \\
\text { (\%) }\end{array}$} \\
\hline \multirow{3}{*}{1.} & Total Non-Oil and Gas Exports (A + B) & (Rp. Billion) & $1.161 .372,5$ & \\
& A. Micro, Small, Medium Enterprises (MSMEs) & (Rp. Billion) & $182.112,7$ & 15,68 \\
& - Micro Business (UMI) & (Rp. Billion) & $15.989,5$ & 1,38 \\
& - Small Business (UK) & (Rp. Billion) & $32.051,8$ & 2,76 \\
& - Medium Business (UM) & (Rp. Billion) & $134.071,4$ & 11,54 \\
& A. B. Large Business & (Rp. Billion) & $979.214,8$ & 84,32 \\
\hline
\end{tabular}

Source: Ministry of Cooperatives and SMEs, 2014

In addition, there are several obstacles for MSMEs that are experienced by many developing countries including Indonesia. These constraints include the problem of lack of raw materials which must be imported from other countries for the production process. Besides that, goods marketing, capital, energy availability, infrastructure and information are also problems that often arise later, including non-physical problems such as high inflation, skills, labor rules and so on. The table below shows the obstacles that are often experienced by countries in Asia including Indonesia. 
International Journal of Economics, Business and Accounting Research (IJEBAR)

Peer Reviewed - International Journal

Vol-2, Issue-4, 2018 (IJEBAR)

ISSN: 2614-1280

http://www.jurnal.stie-aas/ijebar

Table 2. MSME Constraints in Developing Countries

\begin{tabular}{|c|c|c|c|c|c|c|c|c|c|c|c|}
\hline \multirow[t]{2}{*}{ Country } & \multicolumn{11}{|c|}{ Main Constraints } \\
\hline & 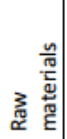 & 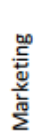 & $\begin{array}{l}\overline{0} \\
\text { 뭉 }\end{array}$ & 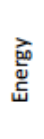 & 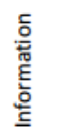 & 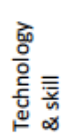 & 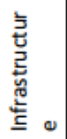 & 希 & 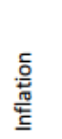 & 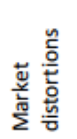 & 总 \\
\hline Indonesia & v & $v$ & $\mathrm{~V}$ & v & 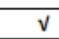 & & & & & & \\
\hline Philippines & & $\sqrt{ }$ & $\mathrm{V}$ & & & v & & & & & \\
\hline Viet Nam & & & $\mathrm{V}$ & & & v & $\sqrt{ }$ & & & v & \\
\hline Cambodia & & & $\mathrm{v}$ & $\sqrt{ }$ & & 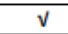 & & & & $\sqrt{ }$ & \\
\hline Lao PDR & v & & $\mathrm{V}$ & & & & & $v$ & $\sqrt{ }$ & & \\
\hline Thailand & v & $\sqrt{ }$ & $\mathrm{V}$ & & $\sqrt{ }$ & v & & & & & \\
\hline Malaysia & $\mathrm{v}$ & & $\mathrm{V}$ & & $\mathrm{v}$ & $\mathrm{v}$ & & & & & \\
\hline Brunei & & $\sqrt{ }$ & $\mathrm{V}$ & & & v & & & & & \\
\hline China & & v & $\mathrm{V}$ & & & v & V & & & & \\
\hline India & & v & $\mathrm{V}$ & & & & v & & & $\sqrt{ }$ & \\
\hline Pakistan & & $\sqrt{ }$ & $\mathrm{V}$ & & & & & & & $\sqrt{ }$ & $\sqrt{ }$ \\
\hline Bangladesh & & & $\mathrm{V}$ & $\sqrt{ }$ & & $\mathrm{v}$ & & & & $\sqrt{ }$ & \\
\hline Nepal & & $\sqrt{ }$ & $\mathrm{V}$ & & & $\mathrm{v}$ & & & & 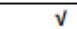 & \\
\hline
\end{tabular}

Source: Tulus Tambunan (2009) in Sudaryanto, et.al (2012)

The importance of empowering MSMEs

Indonesia's population of more than 240 million people (according to the 2010 census), it turns out that only 0.24 percent are entrepreneurs (interpreneur), or only around 400,000 people are involved in the business world or MSMEs. In fact, in order for the Indonesian economy to develop more quickly, more than 2 percent of the population is needed as entrepreneurs or involved in MSMEs. Singapore, a small country but has 7 percent of its population is an entrepreneur and has many MSMEs. Whereas Malaysia, more than 2 percent of the population is interpreneur involved in various micro businesses. Increasing the empowerment of MSMEs will also have an impact on the large number of workers absorbed. In addition, the increase in the MSME sector will also add to Indonesia's Gross Domestic Product (GDP). As explained in table 3, in 2013 MSMEs contributed 60\% to Indonesia's GDP.

Table 3. Data on MSME GDP and Large Businesses

On the basis of Garga Applicable in 2013

\begin{tabular}{|c|l|r|r|r|}
\hline \multirow{2}{*}{ NO } & \multicolumn{1}{|c|}{ INDICATOR } & \multirow{2}{*}{ UNIT } & \multicolumn{2}{c|}{ YEAR 2013 } \\
\cline { 4 - 5 } & & & \multicolumn{1}{c|}{ TOTAL } & \multicolumn{1}{c|}{ MARKET } \\
& & & \multicolumn{1}{c|}{ SHARE (\%) } \\
\hline \multirow{3}{*}{1.} & Total Non-Oil and Gas Exports (A+B) & (Rp. Billion) & $9.014 .915,2$ & \\
& A. Micro, Small, Medium Enterprises (MSMEs) & (Rp. Billion) & $5.440 .007,9$ & 60,34 \\
& - Micro Business (UMI) & (Rp. Billion) & $3.326 .564,8$ & 36,90 \\
& - Small Business (UK) & (Rp. Billion) & $876.385,3$ & 9,72 \\
& - Medium Business (UM) & (Rp. Billion) & $1.237 .057,8$ & 13,72 \\
& B. Large Business & (Rp. Billion) & $3.574 .943,3$ & 39.66 \\
\hline
\end{tabular}

Source: Ministry of Cooperatives and SMEs, 2013 


\section{MSME Empowerment Strategy in Increasing Indonesian Exports Role of the Government}

The development of Micro, Small and Medium Enterprises (MSMEs) in Indonesia is inseparable from banking support in lending to MSMEs. Every year credit to MSMEs grows and generally growth is higher than total bank credit. In Law No. 20 of 2008 Regarding MSMEs, MSME loans are loans to debtors of micro, small and medium enterprises that meet the definition and criteria of micro, small and medium enterprises. Under the Act, MSMEs are productive businesses that meet business criteria with certain limits on net assets and annual sales.

The development of Micro, Small and Medium Enterprises (MSMEs) in Indonesia is also inseparable from the support and role of the government in encouraging lending to MSMEs. Various schemes of MSME credit / financing launched by the government are associated with economic development tasks and programs in certain business sectors, such as food security, animal husbandry and plantations. The government's role in these MSME credit schemes is on the side of providing state budget funds for the intended credit scheme interest subsidy, while the entire credit / financing fund (100\%) comes from banks appointed by the government as executing banks. The credit scheme that is very familiar in the community is the People's Business Credit (KUR), which is specifically intended for MSMEs with a decent business category, but does not have sufficient collateral in the context of banking requirements. KUR is Credit or financing to MSMEs and Cooperatives that are not currently receiving Credit or Financing from Banking and / or who are not receiving Program Credit from the
Government when a Credit / Financing application is submitted. The final goal launched by the KUR Program is to improve the economy, alleviate poverty and absorb employment (Sudaryanto, et.al, 2012).

The government as a regulator, basically has issued a lot of programs or schemes that have been provided to empower MSMEs. This program should continue to be optimized. These programs include.

1. People's Business Credit (KUR), as discussed above.

2. Food and Energy Security Credit (KKPE), KKPE is investment credit or working capital provided in the framework of supporting food security programs, and provided through farmer groups or cooperatives.

3. Agriculture Agribusiness Business Program (PUAP), PUAP is a facilitation of business capital assistance for member farmers, both farmer owners, sharecroppers, farm workers and farm households coordinated by a combination of farmer groups (Gapoktan).

4. Cow Breeding Business Credit (KUPS)

5. Independent Community Empowerment National Program (PNPM)

Likewise the programs issued by State-Owned Enterprises (BUMN) in the form of Partnership and Community Development Program (PKBL). This program departs from the concern of SOEs to empower MSMEs through a share of 2.5 percent of profits used to empower MSMEs. On the other hand, the Ministry of Cooperatives and MSMEs and other Ministries directly provide guidance to MSMEs throughout the country. Including the Directorate General of Tax, the 
Ministry of Finance immediately carries out and provides tax facilities to MSMEs. It is also hoped that the empowerment of MSMEs will be carried out by the private sector through the Corporate Social Responsibility (CSR) they have, among others through the foster father, plasma, management coaching and various activities for marketing MSME products. CSR is expected to be rolled out by the Indonesian banking industry to provide facilities and access to credit for MSME players.

\section{Expansion of Access to Information on Marketing Networks for MSMEs}

In the face of an increasingly open and competitive market mechanism, market control is a prerequisite for increasing the competitiveness of MSMEs. In order to gain control of the market, MSMEs need to get information easily and quickly, both information about the production market and the factor production market. Information about the production market is needed to expand the marketing network of products produced by MSMEs. Information on production markets or commodity markets needed, for example (1) what types of goods or products are needed by consumers in a particular area, (2) how people's purchasing power is for the product, (3) what market prices apply, (4) consumer tastes on local, regional and international markets. Thus, MSMEs can anticipate various market conditions so that their business will be more innovative.

Complete and accurate market information can be utilized by MSMEs to plan their business appropriately, such as making product designs that are preferred by consumers, determining prices that compete in the market, knowing the market to be targeted, and many other benefits. In addition to having ease and speed in obtaining market information, MSMEs also need to have ease and speed in communicating or promoting their business to consumers widely both at home and abroad. So far, the promotion of MSMEs is mostly carried out through joint exhibitions in a limited time and place, so that the relationship and transactions with consumers can not be guaranteed to be sustainable. This can be caused by long distances or constraints on the lack of communication intensity. Though the communication factor in running a business is very important, because with communication will make a strong emotional bond with existing customers, also allows the arrival of new customers (Sudaryanto, et.al, 2012).

\section{Strengthening companion institutions through Increasing Capacity Building}

Setyobudi in Sudaryanto, et. Al. (2007) states that Bank Indonesia focuses more on strengthening MSME escort institutions through capacity building in the form of training and research activities that support lending to MSMEs. Some of the efforts made include:

a. Training for MSME escort institutions, in order to improve MSME credit capabilities

b. Establishment of the SME Companion Development Center (P3UKM), as a pilot project. P3UKM, among others, is in charge of conducting training and accreditation of SME assistants.

c. Development of an Integrated Small Business Development Information System (SIPUK) as a means to more quickly disseminate research results and various other information. SIPUK consists of the Baseline Economic Survey Information System (SIB), 
Export Oriented Agroindustry Information System (SIABE), Information System Pattern for Financing / Small Business Model (SILMUK), Investment Decision Support System (SPKUI); and the Procedure for Obtaining Credit Procedures (SIPMK).

d. Various studies in order to provide information to support the development of MSMEs. Research activities are primarily directed at supporting the establishment of direction and policies of Bank Indonesia in the context of providing technical assistance and also in the context of providing information that is useful in the context of developing MSMEs. The research was adapted to the needs of MSME development and to explore the potential of the MSME sector in each region in Indonesia. In an effort to increase the role of MSMEs to encourage economic growth. Bank Indonesia conducted a study of identification of central and regional regulations in order to develop MSMEs as well as reviewing and implementing cluster MSME development pilot projects.

\section{Human Resource Development for MSMEs through Information Technology}

Information technology is a form of technology used to create, store, change, and use information in all its forms. Through the use of this information technology, micro, small and medium enterprises can enter the global market. The positive things that can be gained by utilizing information technology in developing businesses are: (1) can enhance the promotion of products and services through direct contact, information-rich, and interactive with customers, (2) creating a distribution channel for existing products, (3) the cost of sending information to customers is more efficient when compared to packages or postal services, (4) the time needed to receive or send information is very short, in just minutes or even seconds.

MSMEs in Indonesia with all their limitations can develop by utilizing information technology, needing support in the form of training and provision of facilities. Of course the biggest responsibility for providing training and provision of these facilities is in the hands of the government, in addition to other parties who have commitments, especially the university. This IT-based MSME Development Center needs to be built in each district or if possible in each sub-district. The facility is in the form of a special room equipped with a set of computers connected to the internet, as well as equipped with the UMKM website of each region, under the management and financing of the regional government. This is based on the fact that most MSMEs are located in sub-district villages and cities, and have not been able to have their own internet network, let alone have a website. Even though business development with global market access must utilize virtual media. This IT-based UMKM Development Center will facilitate MSMEs in expanding markets both domestically and overseas markets in a time and cost efficient manner. So that the level of welfare of the MSME community and the labor involved in it will increase, and synergistically will have a positive impact on the success of national development.

Basically, many MSME products in Indonesia have the same quality as 
foreign products, or even better. But these external products often excel in technology, both in production, packaging and marketing technologies. To win the competition, MSMEs must also develop in accordance with the times. With the help of Information and Communication Technology can improve performance so that it is more effective and efficient. So even though there are slight differences in costs with traditional systems, MSMEs can enjoy facilities from IT that will provide a commensurate return. With IT UMKM will be better prepared to compete not only domestically but also with foreign products. We can compete in terms of quality, packaging, and the speed of operations of the company and can increase the performance of exports in Indonesia even greater.

\section{CONCLUSION}

The strategy to develop exports in Indonesia through Micro, Small and Medium Enterprises (MSMEs) is inseparable from banking support in lending. Currently the credit scheme that is very familiar in the community is the People's Business Credit (KUR), in addition to strengthening MSME escort institutions through easy access and increased capacity building in the form of training and research activities in order to increase production from MSMEs.

The strategy to anticipate an increasingly open and competitive market mechanism in strengthening exports is market control, which is a prerequisite for increasing the competitiveness of MSMEs. In order to gain control of the market, MSMEs need to get information easily and quickly, both information about the production market and the production factor market to expand the product marketing network produced by MSMEs.
Information technology applications in micro, small and medium enterprises will make it easier for MSMEs to expand markets both domestically and overseas markets efficiently. The establishment of an IT-based MSME Development Center is considered capable of encouraging the growth and development of micro, small and medium enterprises in the current era of information technology.

\section{BIBLIOGRAPHY}

Sudaryanto, Ragimun, Rahma. "The UMKM Empowerment Strategy Faces the Asean Free Market", accessed from http://www.kemenkeu.go.id / sites / default / files / strategyempowerment-umkm (21 May 2018 at 21.00)

Hasoloan, Jimmy. "The role of International Trade in Productivity and Economy", in Edunomic economic journal scientific education Volume 1 Number 2, 2013: p. 102-112.

Wahyuningsih, Sri. "The Role of MSMEs in the Indonesian Economy", in the Mediagro Journal of agricultural sciences Volume 5. Number 1, 2009: pp. 1-14.

Republic of Indonesia. 2008. Law No. 20 of 2000 concerning Micro, Small, Medium Enterprises. Republic of Indonesia State Gazette 2008, No. 4866. State Secretariat. Jakarta.

Ministry of Cooperatives and SMEs 2013. Data on Micro, Small and Medium Enterprises in 2012-2013. Jakarta is accessed from http://www.depkop.go.id/pdf- 
International Journal of Economics, Business and Accounting Research (IJEBAR)

Peer Reviewed - International Journal

Vol-2, Issue-4, 2018 (IJEBAR)

ISSN: 2614-1280

http://www.jurnal.stie-aas/ijebar

viewer/sandingan_data_umkm_20

12-2013.pdf (May 21 at 8:00 p.m.).

Central Jakarta Statistic Center, 2018. Total Export and Import April 2018. Central Jakarta: Central Statistics Agency.

Central Jakarta Statistic Center, 2018. Small Micro Enterprises. Central Jakarta: Central Agency for Body Statistics.

Central Jakarta Statistics Center, 2018. Population Census 2010. Central Jakarta: Central Statistics Agency.

Republic of Indonesia, Regulation of the Minister of Finance Number 316 / KMK.016 / 1994 concerning Guidelines for the Development of Small Businesses and Cooperatives through the Utilization of Funds from the Institution of StateOwned Enterprises. 